\title{
MOTIVASI PESERTA DIDIK SMK TRIATMAJAYA SINGARAJA MENJAGA KEBUGARAN JASMANI PADA MASA PANDEMI COVID-19
}

\author{
I Wayan Wisma Pratama Putra1, I.K. Budaya Astra², I.G. Suwiwa ${ }^{3}$ \\ ${ }^{123}$ Program Studi Penjaskesrek, Jurusan Pendidikan Olahraga, \\ Fakultas Olahraga dan Kesehatan, \\ Universitas Pendidikan Ganesha, \\ Singaraja-Indonesia \\ Email : wismapratama25@gmail.com, budaya.astra@undiksha.ac.id, \\ suwiwagede@undiksha.ac.id
}

\begin{abstract}
ABSTRAK
Penelitian ini bertujuan untuk mengetahui motivasi peserta didik SMK Triatmajaya Singaraja Menjaga Kebugaran Jasmani Pada Masa Pandemi Covid-19. Penelitian ini adalah penelitian deskriptif kuantitatif denga survei. Populasi dari penelitian ini menggunakan peserta didik kelas XI SMK Triatmajaya Singaraja tahun ajaran 2020/2021 dengan jumlah total sebanyak 232 orang. Metode pemilihan sampel menggunakan non random sampling yaitu quota sampling dengan besaran $25 \%$ dari jumlah total populasi, sehingga jumlah sampel sebanyak 58 orang. Teknik analisis data menggunakan statistic deskriptif kuantitatif dengan kategori interval. Hasil dari penelitian ini yaitu pada faktor intrinsik motivasi peserta didik SMK Triatmajaya Singaraja dalam menjaga kebugaran jasmani pada masa pandemi covid-19 memperoleh skor 79,5 jika dikonversikan ke dalam interval kategori termasuk dalam kategori sangat tinggi. Sedangkan pada faktor ekstrinsik motivasi peserta didik SMK Triatmajaya Singaraja dalam menjaga kebugaran jasmani pada masa pandemi covid-19 memperoleh skor 7,44 jika dikonversikan ke dalam interval kategori termasuk dalam kategori sangat tinggi. Berdasarkan kedua indikator pada variabel, motivasi peserta didik SMK Triatmajaya Singaraja dalam menjaga kebugaran jasmani pada masa pandemi covid-19 memperoleh skor 76,9. Jika dikonversikan ke dalam interval kategori, motivasi peserta didik SMK Triatmajaya Singaraja menjaga kebugaran jasmani pada masa pandemi covid-19 termasuk dalam kategori sangat tinggi. Dengan demikianpeserta didik SMK Triatmajaya Singaraja bisa menjadi contoh untuk peserta didik yang lain agar dapat menjaga dan melaksanakan aktivitas kebugaran jasmani pada masa pandemi covid-19 serta menigkatkan kekebalan tubuh.
\end{abstract}

Kata kunci: Motivasi, Kebugaran Jasmani, Pandemi Covid-19

\section{ABSTRACT}

This research purposed to investigate the motivation of Triatmajaya Vocational School Students in Maintaining Physical Fitness during the Covid19 Pandemic. This research was a descriptive qualitative survey-based study. The population of this research was 232 eleventh-grade students of 
Triatmajaya Vocational School Singaraja in academic years 2020/2021. The sampling technique used was non-random sampling, which the sampling quota was $25 \%$ of the total population, then the sample chosen was 58 students. The data analysis technique used was the descriptive qualitative statistic. The result of this research shows that the intrinsic factor of Triatmajaya Vocational School students' motivation in maintaining physical fitness during the covid-19 pandemic get a score of 79.5 and it belongs to the very high category rating scale. Yet, in the irrelevant factor, the motivation of Triatmajaya Vocational School students in maintaining physical fitness during covid-19 pandemic get a score of 7.44 , which belongs to the very high category rating scale. Based on both indicators in the variable of the motivation of Triatmaja Vocational School students in maintaining physical fitness during covid-19 pandemic get a score of 76.9 means that when converted into category intervals, the motivation of Triatmajaya Vocational School students in maintaining physical fitness during covid-19 pandemic was included in the very high category rating scale. Therefore, the students of Triatmajaya Vocational School can be example for other students to be able to maintain and carryout physical fitness activities during the covid-19 pandemic and increase immunity

Keywords: Motivation, Physical Fitness, Covid-19 Pandemic

\section{PENDAHULUAN}

Penyebaran Virus Corona merupakan ancaman kesehatan global paling serius dalam beberapa dekade terakhir. Sejak pertama kali kasus penyakit Virus Corona ini dilaporkan di Wuhan, Provinsi Hubei, China pada 8 Desember 2019, wabah virus yang kemudian diberi nama Severe Acute Respiratory Syndrome Coronavirus 2 (SARSCOV2) dan menyebabkan penyakit Coronavirus Disease-2019 (COVID-19) terus menyebar secara luas di berbagai negara. Sehingga pada Rabu, 11 Maret 2020, Organisasi Kesehatan Dunia (WHO) menyatakan COVID-19 menjadi pandemi global mengingat penyebaran Virus Corona yang cepat hingga ke wilayah yang jauh dari pusat wabah dan sudah banyak negara di berbagai belahan dunia melaporkan adanya kasus positif COVID19 ini. Bahkan per tanggal 10 April 2020, WHO mencatat ada 212 negara/kawasan telah terkena dampak COVID-19 dengan total kasus positif COVID-19 berjumlah 1.439 .516 orang dan 85.711 kematian (Siagian, 2020).

Jumlah penderita severe acute respiratory syndrome coronavirus 2 (SARS-CoV-2) atau COVID-19 hingga minggu awal di bulan Juni 2020 mencapai $7,039,918$ orang dan menyebabkan 404,396 kematian. Manifestasi COVID-19 dapat menyebabkan acute respiratory distress syndrome (ARDS) dan / atau kegagalan multi-organ (MOF) dan kematian (Lippi, Lavie and Sanchis-Gomar, 2020; Mattiuzzi and Lippi, 2020; Atmojo, Arradini, Ernawati, Darmayanti, and Widiyanto., 2020) (Handayani, 2020).

Perubahan pola hidup sangat terasa ketika pandemi Coronavirus ( Covid-19) seperti 4 bulan belakangan ini meluas dan berdampak ke berbagai negara tak terkecuali negara kita Indonesia. Coronavirus ini merupakan keluarga besar virus yang menyebabkan 
penyakit mulai dari gejala ringan hingga berat. Covid-19 adalah penyakit baru yang belum pernah teridentifikasi sebelumnya pada manusia, gejala dan tanda-tanda umum bila terjangkit virus ini berupa batuk, demam tinggi, dan sesak nafas. Virus ini ditularkan melalui percikan air liur (dropled) saat batuk dan atau bersin. Ketika virus ini sudah memasuki tubuh manusia, ada masa inkubasi dari virus ini selama 5-6 hari bahkan terpanjang 14 hari. Pada tanggal 30 Januari 2020 WHO telah menetapkan kedaruratan kesehatan yang meresahkan dunia. Pada tanggal 2 Maret 2020, Indonesia teridentifikasi positif Covid-19 sebanyak 2 kasus dan terus meningkat dalam 2 minggu, (Dewi, 2020). Dengan hadirnya Coronavirus ini di Indonesia sangat berdmapak bagi seluruh kalangan masyarakat baik sektor ekonomi, sosial, pariwisata serta pendidikan. Setelah dikeluarkannya surat edaran dari Menteri Pendidikan dan Kebudayaan Republik Indonesia Nomor 4 tahun 2020 Tentang Pelaksanaan Kebijanan Pendidikan Dalam Masa Darurat COVID, dalam surat tersebut dijelaskan bahwa segala bentuk proses pembelajaran dilaksanakan di rumah masing-masing dengan melalui pembelajaran jarak jauh/daring.

Setelah dikeluarkan surat edaran untuk masyarakat pemerintah menghimbau agar seluruh masyarakat membatasi aktivitas di luar rumah yang mengumpulkan orang banyak, tak terkecuali dalam pendidikan khususnya pendidikan jasmani. Dalam himbauan pemerintah yang disalurkan ke masyarakat melalui aparatdaerah masing-masing bahwa salah satu cara untuk mencegah manusia tertular sari Covid-19 adalah menjaga kebugaran jasmani. Kebugaran jasmani merupakan merupakan modal dasar bagi seseorang dalam melakukan aktivitas fisik secara berulang-ulang dengan waktu yang relative lama tanpa menimbulkan kelelahan. Aktivitas olahraga sangat mempengaruhi kebugaran jasmani seseorang, aktivitas olahraga memberikan kontribusi langsung pada komponen kebugaran jasmani. Dari sudut pandang IImu Faal Olahraga adlah serangkaian gerak raga yang teratur dan terencana yang dilakukan orang dengan sadar untuk meningkatkan kemmampuan fungsionalnya, sesuai dengan tujuannya melalui olahraga menurut Santosa (dalam Prativi, dkk : 2013). Dalam dunia pendidikan, kebugaran jasmani sangat diperlukan dalam memperlancar aktivitas peserta didik. dengan kebugaranjasmani yang baik maka peserta didik akan mudah dalam menjalankan segala bentuk aktivitas fisiknya dan bisa menjamin seseorang lebih siap dalam melaksanakan tugasnya serat menampilkan penampilan yang optimal. Dengan berubahnya pola belajar peserta didik akibat pandemi menjadikan peserta didik di seluruh Indonesia diarahkan untuk belajar dirumah dengan menggunakan berbagai media pembelajaran yang disarankan oleh pemerintah dan menuntut peserta didik serta guru untuk menguasai berbagai media dalam menunjang pembelajaran di rumah.

Dengan beragamnya media pembelajaran yang digunakan sekarang mau tidak mau peserta didik harus menumbuhkan kreativitas dan motivasimotivasi mereka agar dapat menguasai materi pembelajaran. Bukan hanya materi pembelajaran, tetapi juga harus tetap menjaga kebugaran jasmani mereka. Menurut (Widijoto 2011) media pembelajaran adalah segala sesuatu yang digunakan untuk menyalurkan pesan (bahan pengajaran), sehingga dapat merangsang perhatian, minat, pikiran dan perasaan siswa dalam kegiatan belajar untuk mencapai tujuan pembelajaran tertentu. Seiring dengan perkembangan zaman kemajuan teknologi informasi dan komunikasi ini berlangsung dengan cepat dan menawarkan banyak kemudahan bagi 
manusia dalam memperoleh informasi. Perbedaan jarak, waktu, dan tempat tidak lagi menjadi kendala dalam memperoleh informasi. Pemanfaatan aktivitas kebugaran jasmani dalam bentuk multimedia disebuah $m$-learning pada aktivitas jasmani ini diharapkan dapat melatih dan membantu peserta didik dalam menjaga kebugaran jasmani pada masa pandemi Covid-19 ini. Smartphone adalah benda yang sudah sangat menjamur dimasyarakat dan merupakan benda yang paling sering digunakan dalam kehidupan manusia di setiap harinya. Untuk memanfaatkan smartphone dalam menjaga kebugaran jasmani dengan tujuan membantu dan mempermudah para peserta didik dalam melakukan kegiatan aktivitas jasmani.

\section{METODE PENELITIAN}

Penelitian ini merupakan penelitian deskriptif kuantitatif jenis penelitian survei. Dalam penelitian ini peneliti tidak memberikan perlakuan, namun langsung mengambil data dari sumber data. Penelitian ini dirancang untuk menjelaskan dan mendeskripsikan mengenai Motivasi peserta didik dalam menjaga kebugaran jasmani di masa pandemi covid-19.

Populasi penelitian ini adalah peserta didik kelas XI SMK Triatmajaya Singaraja tahun pelajaran 2020/2021 sebanyak 232 orang. Berdasarkan pernyataan Arikunto (2014) pengambilan sampel yang digunakan dalam penelitian ini menggunakan non random sampling yaitu quota sampling dengan besaran $25 \%$ dari total populasi sehingga jumlah sampel dalam penelitian ini adalah 58 orang. Data penelitian ini dikumpulkan menggunaan instrument penelitian berupa kuisioner yang diisi melalui google form oleh peserta didik. kuisioner ini menggunakan skala likert dengan 4 dimensi penilaian yaitu sangat setuju (SS), setuju (S), tidak setuju (TS), sangat tidak setuju (STS). Data penelitian ini dianalisis menggunakan statistic deskriptif kuantitatif dengan skala penilaian inrterval melalui bantuan Microsoft Exel 2010. Analisis deskriptif digunakan untuk mengetahui motivasi peserta didik berdasarkan deskriptif frekuensi, skala penilaian inrterval yang dikalsifikasikan menjadi Sangat Tinggai, Tinggi, Sedang, Rendah, dan Sangat Rendah.

Tabel 1. Skala Penilaian atau Katagori

\begin{tabular}{cccc}
\hline No & Kriteria & Persentase & Katagori \\
\hline 1. & $\mathrm{Mi}+1.5 \mathrm{SDi}, \leq \mathrm{Mi}+3.0 \mathrm{SDi}$ & $81,25 \%-100 \%$ & Sangat Tinggi \\
2. & $\mathrm{Mi}+0,5 \mathrm{SDi} \leq \mathrm{Mi}+1,5 \mathrm{Sdi}$ & $68,75 \%-80 \%$ & Tinggi \\
3. & $\mathrm{Mi}-0,5 \mathrm{SDi} \leq \mathrm{Mi}+0,5 \mathrm{SDi}$ & $56,25 \%-67,5 \%$ & Sedang \\
4. & $\mathrm{Mi}-1,5 \mathrm{SDi} \leq \mathrm{Mi}-0,5 \mathrm{SDi}$ & $43,75 \%-55 \%$ & Rendah \\
5. & $\mathrm{Mi}-3.0 \mathrm{SDi} \leq \mathrm{Mi}-1.5 \mathrm{SDi}$ & $25 \%-42,5 \%$ & Sangat Rendah \\
\hline & & & (Sumber : Koyan: 2012)
\end{tabular}

Keterangan :

Jumlah Max $=$ skor $\max \times$ jumlah pernyataan

$$
=4 \times 20=80
$$

Jumlah Min $=$ skor $\min x$ jumlah pernyataan

$$
=1 \times 20=20
$$

Nilai Max $(\%)=\frac{\text { Jumlah Max }}{\text { Jumlah Max }} \times 100$

$$
\begin{aligned}
& \frac{80}{80} \times 100 \\
= & 100 \%
\end{aligned}
$$


Nilai Min (\%) $=\frac{\text { Jumlah Min }}{\text { Jumlah Max }} \times 100$

$$
\begin{aligned}
& \frac{20}{80} \times 100 \\
= & 25 \%
\end{aligned}
$$

Mi $=1 / 2 \times($ nilai $\max +$ nilai $\min )$

$$
\begin{aligned}
& =1 / 2 \times 125 \\
& =62,5
\end{aligned}
$$

$$
\begin{aligned}
\text { SDi } & =\frac{1 / 6}{1 / 6} \times(\text { nilai } \max -\text { nilai } \min ) \\
& ={ }^{1 / 6} \times 75 \\
& =12,5
\end{aligned}
$$

\section{HASIL DAN PEMBAHASAN}

\section{Hasil Penelitian}

Data hasil pengukuran motivasi peserta didik SMK Triatmajaya Singaraja

\begin{tabular}{|c|c|c|c|c|c|c|c|c|}
\hline \multirow[t]{2}{*}{ No } & \multirow{2}{*}{ Pernyataan } & \multicolumn{4}{|c|}{$\begin{array}{l}\text { Tanggapan } \\
\text { Responden }\end{array}$} & \multirow{2}{*}{$\mathrm{N}$} & \multirow{2}{*}{$\begin{array}{l}\text { Rata- } \\
\text { Rata }\end{array}$} & \multirow{2}{*}{ Kategori } \\
\hline & & SS & S & $\mathrm{TS}$ & $\begin{array}{c}\text { ST } \\
\text { S }\end{array}$ & & & \\
\hline 1. & $\begin{array}{l}\text { Saya perlu berolahraga pada } \\
\text { masa pandemi covid- } 19 \text {. }\end{array}$ & 40 & 18 & 0 & 0 & 58 & 92.2 & $\begin{array}{l}\text { Sangat } \\
\text { Tinggi }\end{array}$ \\
\hline 2. & $\begin{array}{l}\text { Saya ingin melakukan aktivitas } \\
\text { jasmani dengan mudah. }\end{array}$ & 20 & 38 & 0 & 0 & 58 & 83.6 & $\begin{array}{l}\text { Sangat } \\
\text { Tinggi }\end{array}$ \\
\hline 3. & $\begin{array}{l}\text { Saya tertarik untuk } \\
\text { memperhatikan teknik-teknik } \\
\text { yang dijelaskan dalam aplikasi } \\
\text { kebugaran. }\end{array}$ & 11 & 44 & 3 & 0 & 58 & 78.4 & $\begin{array}{l}\text { Sangat } \\
\text { Tinggi }\end{array}$ \\
\hline 4. & $\begin{array}{l}\text { Aplikasi kebugaran jasmani } \\
\text { sangat menarik bagi saya. }\end{array}$ & 12 & 39 & 7 & 0 & 58 & 77.2 & $\begin{array}{l}\text { Sangat } \\
\text { Tinggi }\end{array}$ \\
\hline 5. & $\begin{array}{l}\text { Saya tertarik untuk mencari } \\
\text { aplikasi kebugaran jasmani. }\end{array}$ & 10 & 41 & 7 & 0 & 58 & 76.3 & $\begin{array}{l}\text { Sangat } \\
\text { Tinggi }\end{array}$ \\
\hline 6. & $\begin{array}{l}\text { Saya tertarik untuk melakukan } \\
\text { aktivitas jasmani yang mudah. }\end{array}$ & 19 & 39 & 0 & 0 & 58 & 83.2 & $\begin{array}{l}\text { Sangat } \\
\text { Tinggi }\end{array}$ \\
\hline 7. & $\begin{array}{l}\text { Aktivitas jasmani merupakan } \\
\text { aktivitas yang menjenuhkan. }\end{array}$ & 3 & 6 & 38 & 11 & 58 & 74.6 & $\begin{array}{l}\text { Sangat } \\
\text { Tinggi }\end{array}$ \\
\hline 8. & $\begin{array}{l}\text { Aktivitas jasmani memberikan } \\
\text { hal yang positif pada diri saya. }\end{array}$ & 31 & 27 & 0 & 0 & 58 & 88.4 & $\begin{array}{l}\text { Sangat } \\
\text { Tinggi }\end{array}$ \\
\hline 9. & $\begin{array}{l}\text { Saya merasa senang dalam } \\
\text { melakukan aktivitas jasmani } \\
\text { pada masa pandemi. }\end{array}$ & 18 & 34 & 6 & 0 & 58 & 80.2 & $\begin{array}{l}\text { Sangat } \\
\text { Tinggi }\end{array}$ \\
\hline 10. & $\begin{array}{l}\text { Saya tidak nyaman dengan } \\
\text { aktivitas jasmani yang sulit } \\
\text { dilakukan. }\end{array}$ & 5 & 28 & 20 & 5 & 58 & 60.8 & Tinggi \\
\hline 11. & $\begin{array}{l}\text { Saya melakukan aktivitas } \\
\text { jasmani dengan sarana yang } \\
\text { memadai }\end{array}$ & 6 & 48 & 4 & 0 & 58 & 75.9 & $\begin{array}{l}\text { Sangat } \\
\text { Tinggi }\end{array}$ \\
\hline
\end{tabular}
dalam menjaga kebugaran jasmani telah diukur menggunakan angket yang diisi dalam google form yang terdiri dari 20 butir pernyataan yang tersaji pada tabel 2.

Tabel 2 . Analisis Data 
Jurnal Ilmu Keolahragaan Undiksha

p-ISSN : 2613-9693 | e-ISSN : 2613-9685

Volume 8 Nomor 2 Tahun 2020

\begin{tabular}{|c|c|c|c|c|c|c|c|c|}
\hline \multirow[t]{2}{*}{ No } & \multirow{2}{*}{ Pernyataan } & \multicolumn{4}{|c|}{$\begin{array}{l}\text { Tanggapan } \\
\text { Responden } \\
\end{array}$} & \multirow{2}{*}{$\mathrm{N}$} & \multirow{2}{*}{$\begin{array}{l}\text { Rata- } \\
\text { Rata }\end{array}$} & \multirow{2}{*}{ Kategori } \\
\hline & & SS & S & TS & $\begin{array}{c}\text { ST } \\
\text { S }\end{array}$ & & & \\
\hline 12. & $\begin{array}{l}\text { Sarana yang ada tidak } \\
\text { membantu dengan baik dalam } \\
\text { melakukan aktivitas gerak. }\end{array}$ & 2 & 16 & 38 & 2 & 58 & 67.2 & $\begin{array}{l}\text { Sangat } \\
\text { Tinggi }\end{array}$ \\
\hline 13. & $\begin{array}{l}\text { Mudahnya mencari aplikasi- } \\
\text { aplikasi kebugaran jasmani di } \\
\text { smartphone }\end{array}$ & 8 & 44 & 5 & 1 & 58 & 75.4 & $\begin{array}{l}\text { Sangat } \\
\text { Tinggi }\end{array}$ \\
\hline 14. & $\begin{array}{l}\text { Berbagai macam aplikasi } \\
\text { sangat membantu saya } \\
\text { menjaga kebugaran jasmani. }\end{array}$ & 9 & 45 & 4 & 0 & 58 & 77.2 & $\begin{array}{l}\text { Sangat } \\
\text { Tinggi }\end{array}$ \\
\hline 15. & $\begin{array}{l}\text { Aktivitas gerak yang ada } \\
\text { diaplikasi kebugaran sangat } \\
\text { membantu. }\end{array}$ & 13 & 42 & 3 & 0 & 58 & 79.3 & $\begin{array}{l}\text { Sangat } \\
\text { Tinggi }\end{array}$ \\
\hline 16. & $\begin{array}{l}\text { Gerakan-gerakan sangat } \\
\text { mudah untuk dilakukan dan } \\
\text { efektif. }\end{array}$ & 12 & 46 & 0 & 0 & 58 & 80.2 & $\begin{array}{l}\text { Sangat } \\
\text { Tinggi }\end{array}$ \\
\hline 17. & $\begin{array}{l}\text { Saya tidak mengetahui } \\
\text { manfaat dari kebugaran } \\
\text { jasmani. }\end{array}$ & 15 & 7 & 33 & 15 & 58 & 75.9 & $\begin{array}{l}\text { Sangat } \\
\text { Tinggi }\end{array}$ \\
\hline 18. & $\begin{array}{l}\text { Saya lebih mudah menjaga } \\
\text { pola hidup sehat dengan } \\
\text { dibantu oleh aplikasi di } \\
\text { smartphone. }\end{array}$ & 9 & 33 & 16 & 0 & 58 & 72.0 & $\begin{array}{l}\text { Sangat } \\
\text { Tinggi }\end{array}$ \\
\hline 19. & $\begin{array}{l}\text { Banyaknya aplikasi di } \\
\text { smartphone membuat saya } \\
\text { lebih leluasa melakukan } \\
\text { aktivitas gerak. }\end{array}$ & 8 & 38 & 11 & 1 & 58 & 72.8 & $\begin{array}{l}\text { Sangat } \\
\text { Tinggi }\end{array}$ \\
\hline 20. & $\begin{array}{l}\text { Saya tidak mengetahui } \\
\text { tentang aplikasi kebugaran } \\
\text { pada smartphone }\end{array}$ & 2 & 16 & 37 & 3 & 58 & 67.7 & $\begin{array}{l}\text { Sangat } \\
\text { Tinggi }\end{array}$ \\
\hline
\end{tabular}

Keterangan:

SS : Sangat Setuju

S: Setuju

TS : Tidak Setuju

STS : Sangat Tidak Setuju

$\mathrm{N}$ : Jumlah Responden

Tabel 3. Hasil Analisis Deskriptif

\begin{tabular}{ccccc}
\hline NO & Indikator & Jumlah responden & $\begin{array}{c}\text { Rata- } \\
\text { Rata }\end{array}$ & Kategori \\
\hline 1 & Faktor Intrinsik & 58 & 79,5 & Sangat Tinggi \\
2 & Faktor Ekstrinsik & 58 & 74,4 & Sangat Tinggi \\
\hline
\end{tabular}




\section{Pembahasan Hasil Penelitian}

Berdasarkan tabel 3 diatas, dari hasil analisis 10 pernyataan motivasi intrinsik bila dirata-ratakan memperoleh rata-rata skor 79,5 bila dikonversikan pada skala penilaian inrterval katagori motivasi intrinsik dalam kategori Sangat Tinggi. Sedangkan hasil analisis 10 pernyataan motivasi ekstrinsik bila dirata-ratakan memperoleh rata-rata skor 74,4 bila dikonversikan pada tabel Rumus :

$$
\begin{aligned}
& \text { Motivasi }=\frac{\bar{x} 1+\bar{x} 2}{2} \\
& =\frac{79.5+74.4}{2} \\
& =76.9
\end{aligned}
$$

Berdasarkan kedua indikator pada variabel motivasi peserta didik SMK Triatmajaya Singaraja diperoleh rata-rata skor 79,6, bila dikonversikan ke dalam tabel skala penilaian inrterval katagori berada pada katagori sangat tinggi.

\section{PENUTUP \\ Simpulan}

Berdasarkan hasil penelitian yang diperoleh dalam penelitian ini yaitu peserta didik SMK Triatmajaya Singaraja memiliki motivasi intrinsik dan ekstrinsik dalam menjaga kebugaran jasmani pada masa pandemi covid-19 yang digolongkan dalam kategori baik berdasarkan analisis interval. Hasil analaisis data menggunakan deskriptif kuantitatif motivasi peserta didik SMK Triatmajaya Singaraja menjaga kebugaran jasmani pada masa pandemi covid-19 memperoleh skor 79,6 pada tabel skala penilaian inrterval katagori berada pada katagori sangat tinggi. Artinya motivasi peserta didik SMK Triatmajaya menjaga kebugaran jasmani pada masa pandemi covid-19 dalam kategori sangat tinggi. skala penilaian inrterval katagori motivasi ekstrinsik dalam kategori sangat tinggi.

Berdasarkan rata-rata skor yang diperoleh pada setiap komponen indikator motivasi yang dibagi menjadi indikator motivasi intrinsik dan indikator motivasi ekstrintik dari 58 orang peserta didik sebagai sampel dalam penelitian memperoleh rata-rata motivasi sebagai berikut :

\section{Saran}

Berdasarkan kesimpulan penelitian diatas,adapun beberapa saran yang dapat diberikan sebagai berikut:

Kepada peserta didik dari hasil survey agar menjadi lebih termotivasi dalam menjaga kebugaran jasmani guna mencegah penularan covid-19 ddengan cara meningkatkan kebugaran jasmani melalui aktivitas jasmani. Kepada guru yang melaksanakan pembelajaran daring, agar selalu mengingatkan dan memotivasi peserta didik agar tetap menjaga kesehatan melalui kebugaran jasmani di tengah masa pandemi covid19 ini. Saran kepada peneliti lain yang berminat mengadakan penelitian lebih lanjut mengenai survey motivasi peserta didik dalam menjaga kebugaran jasmani pada masa pandemi covid-19 menjadikan hasil penelitian ini sebagai salah satu referensi untuk meneliti dalam ruang lingkup yang lebih luas, sehingga diperoleh sumbangan ilmu yang yang lebih baik dan sesuai dengan perkembangan zaman dan diperoleh dalam penelitian objektif.

\section{DAFTAR PUSTAKA}

Arikunto, Suharsini, 2006. "Prosedur Penelitian Suatu Pendekatan Praktik". Jakarta : PT Rineka Cipta

Arikunto, Suharsini, 2014. "Prosedur Penelitian Suatu Pendekatan Praktik'. Jakarta : PT Rineka Cipta 
Dewi, W. A. F. (2020). Dampak Covid-19 terhadap implementasi pembelajaran daring di Sekolah Dasar. Edukatif: Jurnal IImu Pendidikan, 2(1), 55-61.

Handayani, Rina Tri. 2020. Pandemi Covid-19, Respon Imun Tubuh, Dan Herd Immunity. Jurnal IImiah STIKES Kendal Volume 10 No 3, Hal 373 - 380, Juli 2020.

Irianto, D P. (2004). Pedoman Praktis Berolahraga. Yogyakarta: Andi Offset

Koyan, I Wayan. 2012. Statistika Pendidikan, Teknik Analisis Data
Kuantitatif. Singaraja: Universitas Pendidikan Ganesha.

Siagian, Tiodora Hadumaon. 2020. Mencari Kelompok Berisiko Tinggi Terinfeksi Virus Corona Dengan Discourse Network Analysis. Jurnal Kebijakan Kesehatan Indonesia VOLUME 09 Artikel Penelitian 98 - Jurnal Kebijakan Kesehatan Indonesia : JKKI, Vol. 09, No. 02 Juni 2020.

Prativi, G. O. (2013). Pengaruh Aktivitas Olahraga terhadap Kebugaran Jasmani. Journal of Sport Science and Fitness, 2(3). 